\title{
A Case Report of Hyperhidrosis with Sympathicotonia Detected by Iris Diagnosis
}

\author{
Kyeong-seok Wang ${ }^{1}$, In-cheol Chae ${ }^{1}$, Mi-so Park ${ }^{1}$, Su-a Son ${ }^{1}$, Seong-il Park², Ho-ryong Yoo ${ }^{1}$ \\ 'Dept. of Cardiology and Neurology of Korean Medicine, College of Korean Medicine, Dae-Jeon University \\ ${ }^{2}$ Park Seung-II Korean Medicine Clinic
}

\section{A Case Report of Hyperhidrosis with Sympathicotonia Detected by Iris Diagnosis}

\author{
Kyeong-seok Wang ${ }^{1}$, In-cheol Chaee, Mi-so Park ${ }^{1}$, Su-a Son ${ }^{1}$, Seong-il Park ${ }^{2}$, Ho-ryong Yoo ${ }^{1}$ \\ ${ }^{1}$ Dept. of Cardiology and Neurology of Korean Medicine, College of Korean Medicine, Dae-Jeon University \\ 2Park Seong-II Korean Medicine Clinic
}

\begin{abstract}
Objective: The aim of this case study was to describe a case of iris diagnosis of primary hyperhidrosis and the use of Korean medicine.

Methods: A patient with symptoms of hyperhidrosis was diagnosed as having Taeeumin after assessment using the four basic Korean diagnostic methods. Iris diagnosis was used for further examination. The images obtained showed a remarkably defined collarette and increased nerve rings, which suggested an overactive sympathetic nerve system. Under the diagnosis of Taeeum, a Korean herbal medicine was prescribed with additional herbs to help alleviate the hyperactivity of the sympathetic nervous system.

Results: The patient had been receiving treatment for hyperhidrosis for $>30$ years, with various medical attempts to relieve her symptoms, which were ineffective. She showed signs of improvement from day 4 into the treatment, and $80 \%$ of her symptoms were improved after completing a 6-week treatment course.

Conclusion: The herbal medicine prescribed to the patient proved effective for reducing her chronic symptoms that had been unresponsive to previous medical treatments.
\end{abstract}

Key words: primary hyperhidrosis, Korean medicine, iridology, hyperactive sympathetic nervous system, Sasang constitution

\section{Introduction}

Hyperhidrosis is a clinical disorder characterized

· 투고일: 2021.09.17, 심사일: 2021.11.04, 게재확정일: 2021.11.04

- Corresponding author: Ho-ryong Yoo Dept. of Cardiology and Neurology of Korean Medicine, College of Korean Medicine, Dae-Jeon University, 62, Daehak-ro, Dong-gu, Daejeon, Korea TEL: +82-42-470-9131

E-mail: hryoo@dju.kr by excessive sweating. Depending on the cause of the condition, hyperhidrosis is classified as either primary hyperhidrosis or secondary hyperhidrosis, also it can affect the entire body or certain parts of the body. Primary hyperhidrosis is generally regarded as the localized hyperhidrosis that affects only certain parts of the body and is caused by the imbalance of sympathetic and parasympathetic nerves in the autonomic nervous system ${ }^{1}$. 
According to a Japanese epidemiological study of primary hyperhidrosis, $5.33 \%$ of excessive sweating occurs on the palm, $2.79 \%$ in the armpits while $4.7 \%$ affects the head area ${ }^{2}$. According to a university hospital in South Korea, 34.1\% of patients with the condition had a known family history, the condition becomes apparent during the teenage years ${ }^{3}$.

According to the statistics from the Health Insurance Review \& Assessment Service of Korea, more than 7000 people received hospital treatments for primary hyperhidrosis (R610) between 2016 and 2019, and 70\% of patients aged between 10 and 30. Primary hyperhidrosis has an onset during the teenage years when older adults are rarely affected by the condition ${ }^{4}$.

In modern medicine, hyperhidrosis is often managed with non-invasive techniques, involving anticholinergic drugs or topical applications of aluminium chloride solutions on the affected areas. This has a relatively good effect in reliving the symptoms. However, the result is often temporary. Some invasive treatments - used in modern medicines - include the botulinum toxin (Botox) injections, eccrine gland disruption using laser or ultrasound and endoscopic thoracic sympathectomy (ETS) a surgery in which involves destroying a portion of the sympathetic nerve trunk in the thoracic region ${ }^{5.6}$. ETS has been considered an effective treatment the hyperhidrosis. However, despite its well-established success rate, ETS can also cause some fatal complications such as surgical infections while removing the sweat glands and some compensatory sweating?

Due to the limitations and the risk of adverse effects associated with modern medical treatments, the number of patients with hyperhidrosis who become interested in trying Korean medicine treatments is steadily growing ${ }^{8}$. Furthermore, medical studies evidencing the efficacy of Korean medicine to treat hyperhidrosis are published continuously. In Korean medicine, hyperhidrosis is regarded as a fever in gastric organs, cardiomyopathy and weakened qi. Basic herbal medicine prescribed to treat hyperhidrosis include: Jinaetang, Daeshihotang, Gamipalmultang, Bohyolansintang, Bojungikgitang, D anguiyukhwangtang ${ }^{9,10}$.

Iris diagnosis is a registered diagnostic method used in Korean medicine practice. The iris is a cranial nerve tissue made from the ectoderm of the brain that begins to form from the 4th week of embryonic development ${ }^{11}$. As an organ, the iris controls the amount of light pass through the back of the eyes. It is widely studied that the iris represents major parts of the organs and that several genetic conditions can be detected by looking at the iris ${ }^{12}$. The Korean iris diagnosis is based on the analysis of the genetic markers that include colours, structures, pigments, decolourization, nerve ring, etc. These elements play an important role in understanding Han-Yeol-Jo-Seup (cold-heat -dry-wet) types in Sasang constitutions and also evaluating the performance of the five major organs $^{13}$.

In this case study, the patient with hyperhidrosis was first diagnosed her Sasang constitution, using the Korean medicine diagnostic method and further examined with iridology. The results indicated that her sympathetic nervous system was hyperactive. Consequently, a Korean herbal medicine was prescribed to the patient to improve her condition. Even though her conditions weren't relieved with several medical treatments she tried in the past, the result of this trial was highly positive. 


\section{Case}

\section{A. IRB Review}

This case study investigates a 37-year-old female patient with hand and foot hyperhidrosis, visiting the hospital from June 152021 to July 17 2021. The study follows the Case Report Guidelines (CARE guidelines) also it has been reviewed by the IRB 1040647-202108-HR-004-01.

\section{B. History}

On the 14th of June, the patient made her first hospital visit due to hand and foot hyperhidrosis. The condition became apparent at the age of 7 and gradually worsened. In her adolescent years, she had to take 3 to 4 handkerchieves to wipe her hands at exams. She was suggested to consider surgery by a Western medicine hospital. However, the patient objected to the surgery due to the potential adverse effects. At the age of 37, working as a psychologist, her excessive sweating on her hands and feet disrupted her daily routines and caused social withdrawal. When suggested a Korean medicine treatment for hyperhidrosis, the patient was hesitant at first, as all her previous medical attempts made weren't satisfactory. However, she agreed to try the Korean herbal medicines after a couple of days of consideration.

\section{Examination findings}

At the first consultation, the patient's palms were drenched in sweat, and the consulting form she was holding were wet. She is $161 \mathrm{~cm}$ in height, $68 \mathrm{~kg}$, BMI 26.23, slightly yellow-toned skin and overweight. Her tongue was coated with yellow and white fur while her pulses were floating and tight. Other areas such as her appetite, digestion, urine, sleep, menstrual patterns were within a normal range. The abdomen examination indicated that she was Taeeum constitution also she had a low level of abdomen discomfort. She was easy to flush and tensed when stressed.

Dr Camscope Pro LED (Sometech, Seoul, Korea, Fig. 1) was used for iris photographing device. The installed LED lamp has a colour temperature of $6500 \mathrm{~K}$, close to the natural light. The photographing procedures were as follow: The patient is seated in a chair, rested for a while. The patient places her eye in close contact with the device to prevent any ambient light interferences. Allowed a couple of seconds to adapt the LED light coming from the device. Repeated the same procedures for the other eye. The photography resolution was set to $1280 \times 960$ pixels, and the $75 \mathrm{~mm}$ long eyepiece magnified the view by 25 times.

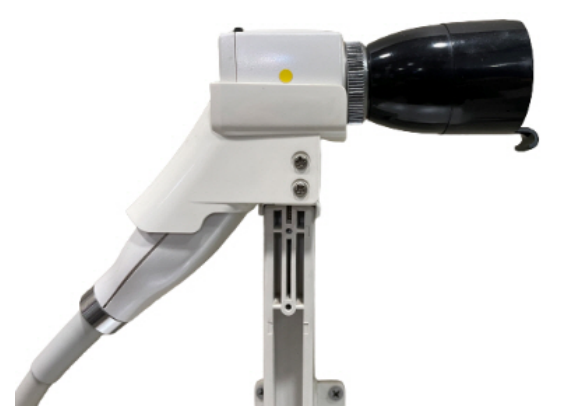

Fig. 1. Dr. Camscope Pro LED (75 mm eye piece attached, Sometech, Seoul, Korea).

According to the iris image(Fig. 2) taken for diagnosis, the diagnostic markers, such as Lacuna, Crypts had neither defects nor weakened tissues. However, the Collarette and Nerve rings were notably defined and thick, which indicated that her sympathetic nerve glands were overly active ${ }^{14}$. 


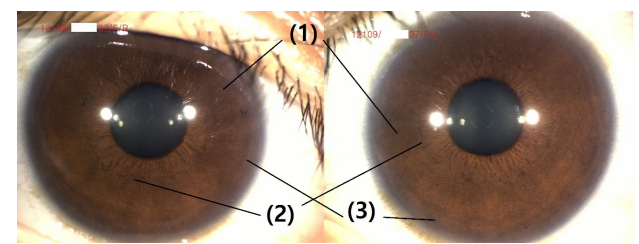

Fig. 2. The numbered lines point toward pathophysiological markers of the patient's iris.

(1) wet type, (2) collarette, (3) nerve ring

\section{Therapeutic Intervention}

According to the examination findings, herbal medicines were formulated following the recipes of Taeeumjowi-tang and Banhabaekchulcheonma-tang which was aimed at relieving excessive fluid retention and reducing hyperactivity in the sympathtic nervous systems in the brain were used with additional use of Bupleuri Radix, Coptidis Rhizoma, Scutellariae Radix $^{15}$ to help suppress hyperactive sympathetic nerve systems and Artemisiae Capillaris Herba, Cocicis Semen, Alimatis Rhizoma, Polyporus to relieve water retention and heat.

One dosage contains a $100 \mathrm{cc}$ herbal drink, directed to take twice a day for 30 days. The ingredients and usage per dose are as follows (Table 1):

\section{E. Assessment Methods}

The Hyperhidrosis Disease Severity Scale (HDSS) formulate by the Canadian Hyperhidrosis Advisory Committee was used to assess the severity of the condition. HDSS is the most widely used measurement of treatment efficacy in clinical studies. A 1-point improvement in HDSS score has been associated with a 50\% reduction in sweat production and a 2 -point improvement with an $80 \%$ reduction. It is one simple question with four answers designed to provides a qualitative measure of the severity of the patient's condition based on how it affects daily activities $^{16}$ (Table 2).
Table 1. Composition of Taeeumjowi-tang and Banhabaekchulcheonma-tang Gagambang

\begin{tabular}{|c|c|c|}
\hline $\begin{array}{l}\text { Herb } \\
\text { medicine }\end{array}$ & Latine name & $\begin{array}{l}\text { Dose }(\mathrm{g}) \\
\text { per day }\end{array}$ \\
\hline 白 术 & $\begin{array}{c}\text { Atractylodes macrocephala } \\
\text { Koidzumi }\end{array}$ & 4 \\
\hline 麥 芽 & Hordeum vulgare Linné & 4 \\
\hline 山藥 & Dioscoreae Rhizoma & 4 \\
\hline 牡 蠣 & Ostreae Testa & 3 \\
\hline 茵蔯蒿 & Artemisiae Capillaris Herba & 3 \\
\hline 金銀花 & Lonicerae Flos & 2 \\
\hline 山 査 & Crataegi Fructus & 2 \\
\hline 黃＼cjkstart芪 & Astragali Radix & 2 \\
\hline 澤＼cjkstart瀉 & Alismatis Rhizoma & 2 \\
\hline 白获苓 & Poria Sclerotium & 1 \\
\hline 砂 仁 & Amomi Fructus & 1 \\
\hline 薏莰仁 & Coicis Semen & 1 \\
\hline 天 麻 & Gastrodiae Rhizoma & 1 \\
\hline 遠＼cjkstart志 & Polygalae Radix & 1 \\
\hline 麻 黃 & Ephedra sinica Stapf & 1 \\
\hline 甘＼cjkstart草 & Glycyrrhizae Radix et Rhizoma & 1 \\
\hline 蓮子肉 & Nelumbinis Semen & 1 \\
\hline 熟地黃 & Rehmanniae Radix Preparata & 1 \\
\hline 白苟藥 & Paeoniae Radix & 1 \\
\hline 麥門冬 & Liriope platyphtlla Wang et Tang & 1 \\
\hline 烏 梅 & Mume Fructus & 1 \\
\hline 竹 瀝 & $\begin{array}{l}\text { Phyllostachys bambusoides } \\
\text { SIEB. et ZUCC. }\end{array}$ & 1 \\
\hline 當＼cjkstart歸 & Angelicae Gigantis Radix & 0.5 \\
\hline 黃＼cjkstart芩 & cutellaria baicalensis Georgi & 0.5 \\
\hline 槬 子 & Gardenia jasminoides Ellis & 0.5 \\
\hline 連＼cjkstart趣 & orsythia viridissima Lindley & 0.5 \\
\hline 黃＼cjkstart蓮 & Coptis japonica Makino & 0.5 \\
\hline 肉 桂 & Cinnamomi Cortex & 0.5 \\
\hline 桂＼cjkstart枝 & Cinamon twigs, Cassia twigs & 0.5 \\
\hline 地骨皮 & Lycium chinense Miller & 0.5 \\
\hline 五味子 & Schisandra chinensis Baillon & 0.5 \\
\hline 柴 胡 & upleurum falcatum Linne & 0.5 \\
\hline 猪＼cjkstart苓 & Polyporus umbellatus & 0.25 \\
\hline 白茅根 & Imperata cylindrica & 0.25 \\
\hline 拘杞子 & Lycii Fructus & 0.25 \\
\hline 鹿＼cjkstart咠 & Cervi Pantotrichum Corn & 0.5 \\
\hline
\end{tabular}


Table 2. The Hyperhidrosis Disease Severity Scale

Question : How would you rate the severity of
your hyperhidrosis?

\section{F. Treatment course}

The patient had an HDSS score of 4 at the initial hospital visit made on June 14, 2021. On June 18, 3 days into her treatment showed no sign of improvement. Due to the patient moving homes, she came back to the hospital on 11 July. She explained her symptoms began to improve from day 4, and sweating still affects her daily activities but the amount had reduced by $50 \%$. Her HDSS score at this time was 3. On her following visit on July 17, she stopped taking the medicine due to stomach discomforts by 10 days, her HDSS score stayed at 3. On her final visit, 28 July, she explained that her sweating seldom affected her daily activities, with an HDSS score of 2 .

Table 3. Treatment Course

\begin{tabular}{cccc} 
Date & Duration & Condition & Remarks \\
\hline 14 June 2021 & & HDSS 4 & Initial consultation \\
17 June 2021 & & HDSS 4 & Prescribed (taken from the 18th June 2021) \\
21 June 2021 & 3rd day & HDSS 4 & \\
& & \\
11 July 2021 & 13rd day & HDSS 3 & Symptoms reduced from the 4th day Stomach discomforts. \\
17 July 2021 & 18th day & HDSS 3 & The treatment delayed by 10 days. \\
28 July 2021 & 29th day & HDSS 2 & \\
\hline
\end{tabular}

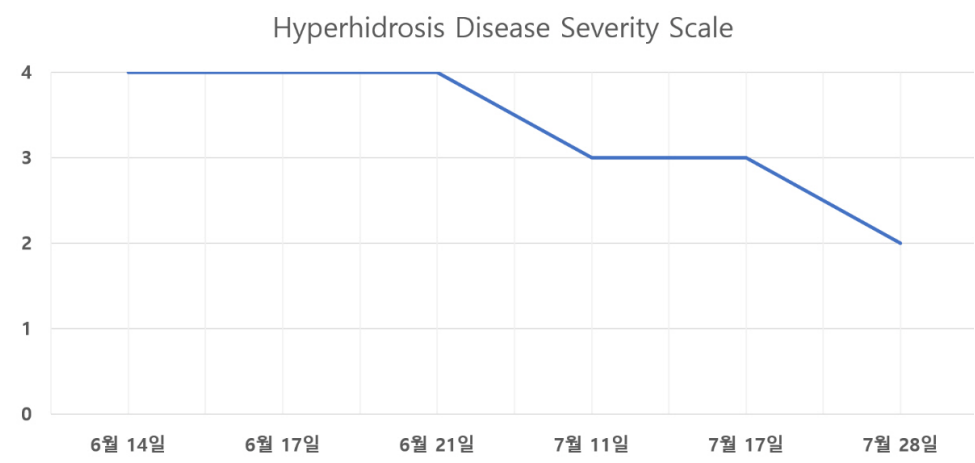

Fig. 3. Progress graph (HDSS). 


\section{Conclusion and Consideration}

For the last 30 years, the patient has experienced physical and emotional discomforts due to excessive sweating on her hands and feet. Through iridology, we diagnosed her conditions, recognised the causes and prescribed a herbal medicine formulated based on Banhabaekchulcheonma-tang, Taeeumjowi-tang Gamibang to relieve excessive fluid retention with additional herbs such as Gastrodiae Rhizoma, Polygalae Radix, Bupleuri Radix, Lonicerae Flos to reduce hyperactivity in the sympathetic nervous systems in the brain. It showed that the patient's stress-induced sweating had decreased in frequency and severity during the 6 weeks of our treatment course. Consequently, a significant result was obtained illustrating that sweating in the hands and feet was reduced by more than $80 \%$ compared to before taking the herbal medicine treatment.

In modern medicine, anticholinergic drugs are used on the affected areas to block the tubes leading from sweat glands to the skin surface. Anticholinergic drugs are used once a day on an affected area for up to 4 weeks. About 60\% to $70 \%$ of patients describe that sweating reduced by $50 \%{ }^{17}$. In this case study, the patient was given a 5 -week course of herbal medicine. On competition of the course, it was demonstrated that sweating was significantly reduced by $70 \%$ in which could be regarded as a more effective treatment for hyperhidrosis in comparison to the modern treatments involving anticholinergic drugs.

These are the type of Byeonjeung(pattern differentiation) used in treating hyperhidrosis using Korean medicines: Jangbu-Byeonjeung, Sasang Constitution Byeonjeung, Yukgyeong-Byeonjeung, Gihyeol-Byeonjeung. For treating Jangbu-Byeonjeung, following Byeonjeung were used: Biwiseupdam, Biwigiheo, Wiyeol, Simbiyangheo, Simbyeongjeung, Gandamseubyeolhaju and Sineumheo. For Sasang Constitution Byeonjeung, Hyunggyeongnyeoljeung, Sinyeoldutongmangeumjeung were used for Soyangin while Wiwanhanjeung was used for Taeeumin, Ulgwangjeung, Taeeumbyeong-Gworeumjeung and Mangyangjeung for Soeumin. There were cases of Yukgyeong-Byeonjeung being diagnosed as Taeyangbyeong-Geolhyungjeung and Gwoleumbyeong. Qihyeol-Byeonjeung was categorized either Qiheo and Qichehyeoleo.

In this case study. the diagnosis of the hyperactive sympathetic nervous system was made based on the diameter and thickness of collarette and nerve rings in the iris. In Fig. 1, the collarette in (2) is appearing thicker than average which indicates that the sympathetic nervous system is overly active ${ }^{18}$. Divided by collarette, Iris sphincter and iridodilator contract and relax sympathetic and parasympathetic nerves ${ }^{19}$. Yung-Hui Li defines 5 constitutions by the shapes of collarette. When collarette is positioned lesser than $1 / 3$ diameter of iris the constitution is defined as Fire $^{20}$. In this case study, the patient's collarette was shorter than 1/3 diameter of the iris, categorized as 'Fire.'. In Korean medicine 'Fire' represents fever therefore diagnosing heat in sympathetic nervous systems in this case study ${ }^{21}$. The nerve ring is the bright-line appearing outer side of the ciliary body. This is a physiological and pathological marker that can detect abnormal stimulation of the sympathetic nervous system. It is related to the thickness and density of the iris and is determined by the hypoplasia or density of some or all of the five cell membranes in the iris. Larsson conducted a study investigating a correlation between personality 
traits and iris ${ }^{22}$. His finding suggests the nerve rings were associated with neurotic behaviours such as impulsiveness. It suggests that people with a higher number of nerve rings had lower ability to control desires and impulses. In particular, the patterns of the $\operatorname{Pax}^{-6}$ gene in the iris and brain also differences in iris tissues and brain structures influence a person's personality. The sympathetic nervous system is shown in the iris and the $\mathrm{Pax}^{-} 6$ gene expression in the brain, the nervous tension glands in the iris show differences in the tissues of the iris and differences in brain structure ${ }^{23}$. The nerve ring in the iris was an important marker for examining sympathetic nervous systems in the brain, especially, the $\operatorname{Pax}^{-} 6$ genes also the differences in iris tissues and brain structures. Based on his findings, we could argue that the nerve rings in the iris could be seen as an important diagnostic marker for hyperactivity in the sympathetic nervous systems.

In this case study, we used iridology to diagnose hyperactivity in sympathetic nervous systems and prescribed Korean herbal medicine to treat a patient with chronic hyperhidrosis which persisted over 30 years. With our course of treatment the patient's symptoms were significantly reduced by $80 \%$. However, it is just one case study with limitations. We believe that further diagnostic examinations, reviewing the changes in central nervous systems more objectively, using autonomic nerve testing (heart rate variability, HRV) would be much needed in the future.

\section{References}

1. National Korean Medicine University Textbook of Dermatology. 6th Edition. Seoul: Koreauihak;
2015, p. $543-54$.

2. Fujimoto T, Kawahara K, Yokozeki H. Epidemiological study and considerations of primary focal hyperhidrosis in Japan: From questionnaire analysis. Journal of Dermatology 2013;40(11):886-90.

3. Park EJ, Han KR, Choi H, Kim DW, Kim C. An epidemiological study of hyperhidrosis patients visiting the Ajou university hospital hyperhidrosis center in Korea. $J$ of Korean Med Sci 2010;25(5) :772-5.

4. "Health Care Bigdata Hub", Disease subdivision statistics(4th disease name) (Search term "local hyperhidrosis, R610'), accessed on August 23, 2021, http://opendata.hira.or.kr/op/opc/olap4thDsInfo.do

5. Wecher T, Feldman SR, Taylor SL. The treatment of primary focal hyperhidrosis. Skin Therapy Lett 2019;24(1):1-7.

6. Atkins JL, Butler PE. Hyperhidrosis: a review of current management. Plast Reconstr Surg 2002;110(1) :222-8.

7. Choi BC, Sim SB, Kim YH, Sa YJ, Park JK, Lee SH. Long Term Outcome of Endoscopically Clipping the Upper Part of R4 Sympathetic Block and R4 Sympathetic Block for the Treatment of Palmar Hyperhidrosis. Korean $J$ Thorac Cardiovasc Surg 2007;40(11):752-8.

8. Lee SH, Baek JH. A Review of Korean Medicine Treatment for Hyperhidrosis. J Pediatr Korean Med 2019;33(3) : 42-55.

9. Her J. Dongeuibogam. Seoul: Namsandang; 2001, p. $123-5$.

10. National College of Korean Traditional Medicine Neuropsychiatry Textbook Compilation Committee. Korean Traditional Medicine Neuropsychiatry. Paju: Jipmundang; 2007, p. 393.

11. Moore and Persaud. Ko JS, Ko JS, Kim KY translation. Human Embryology. Seoul: Jeongmungak; 
1998, p. 461-6.

12. Ernst E. Iridology: A Systematic Review. Forsch Komplementarmed 1999:6(1) :7-9.

13. Park SI, Lim YW. Iris diagnosis and genetic constitution medicine. Daejeon: IGCM; 2017, p. 33-59, 120-4.

14. Park SI, Lim YW. Iris diagnosis and genetic constitution medicine. Daejeon: IGCM; 2017, p. 70.

15. Pharmacognosy Compilation Committee. Pharmacognosy. Paju: Dongmyeongsa; 2018, p. 171, 234, 322.

16. Shin YJ, Kim YH, Yang HJ, Lee JW. Review of the Clinical Evaluation of Hyperhidrosis. Journal Internal Korean Medicine 2015; spr:143-56.

17. Glaser D A, Hebert AA, Nast A, Werschler WP, Green L, Mamelok R, et al. Topical glycopyrronium tosylate for the treatment of primary axillary hyperhidrosis: Results from the ATMOS-1 and ATMOS-2 phase 3 randomized controlled trials. Journal of the American Academy of Dermatology
2019;80(1) :128-38.e2.

18. Park SI, Lim YW. Iris diagnosis and genetic constitution medicine. Daejeon: IGCM; 2017, p. 43.

19. Kim YS, Park YB translation. Autonomic nerve diagnosis. Seoul: Gunjachulpansa; 2007, p. 330-5.

20. Li YH, Aslam MS, Yang KL, Kao CA, Teng SY. Classification of Body Constitution Based on TCM Philosophy and Deep Learning. Symmetry 2020;12(5):803.

21. Park SI, Lim YW. Iris diagnosis and genetic constitution medicine. Daejeon: IGCM; 2017, p. 43.

22. Larsson M, Pedersen NL, Stattin H. Associations between iris characteristics and personality in adulthood. Biological Psychology 2007;75(2):165-75.

23. Choi SH, Park MS, Park SI, Yoo HR. The Case report of a Chronic Candida Vaginatis Patients with Nerve ring and Pigment Spot in the Iris Diagnosis. Journal of Haehwa Medicine 2021; $30(1): 42-9$.

\title{
홍채로 진단한 교감항진 국소다한증 치험례
}

\author{
왕경석 ${ }^{1},^{\text {친철 }}{ }^{1}$, 박미소 ${ }^{1}$, 손수아 ${ }^{1}$, 박성일 $^{2}$, 유호룡 ${ }^{1}$ \\ ${ }^{1}$ 대전대학교 한의과대학 심계내과학교실, ${ }^{2}$ 박성일한의원
}

\section{ABSTRACT}

목적: 국소다한증 환자의 홍채진단을 사용한 변증 및 한의 치료에 대한 연구

방법: 국소다한증을 호소하여 내원한 환자에게 한의학 기본 진단법인 사진법을 사용하여 태음인임을 진단하였다. 그리고 카메라를 사용하여 홍채를 촬영하였고, 얻어진 이미지에서 교감신경항진과 관련된 표지인 권축륜의 선명하고 굵은 모습과 다 수의 신경긴장선이 존재하는 모습을 통해 교감신경이 항진되어 있음을 확인하였다. 태음인 체질방을 기본으로 교감신경 항진 을 조절하는 약재를 가미한 한약처방을 1 개월간 복용하도록 하였다.

결과: 다양한 치료에도 호전되지 않던 30 년 가까이 된 수족 다한증이 한약치료를 통해 복약 4 일차부터 감소하기 시작하여 6 주 만에 치료 시작 전과 비교하여 $80 \%$ 호전되었다.

결론: 만성적이고 다양한 치료에도 반응하지 않던 수족 다한증에 한약 치료가 효과적일 수 있음을 이번 연구를 통해 보고 한다.

중심단어: 국소다한증, 한의학, 홍채진단, 교감신경, 사상체질 